\title{
Cultivation of rose (Rosa indica L.)
}

\section{Abdul Jalil Leghari*, Umed Ali Laghari, Abdul Hafeez Laghari, Tofique Ahmed Bhutto}

Department of Agronomy, Sindh Agriculture University, Tando Jam, 70060, Pakistan

Received: 30.01 .2016

Accepted: 07.05.2016

Published: 13.05.2016

*Address for correspondence:

Abdul Jalil Leghari, Department of Agronomy, Sindh Agriculture University, Tando Jam, 70060, Pakistan. E-mail: laghariabduljaleel@ gmail.com

\begin{abstract}
Rose, locally called Gulab-Jo-Gul (in Sindhi), belongs to family Rosaceae. Its botanical name is Rosa indica L. in the order Rosales. Rosaceae is a larger plant family, which has hundreds of genera and over thousands of species including shrubs, herbs, and trees. Rose is a very much important plant from various aspects. It is widely used throughout the world for love moments, medical purposes, cosmetic uses, happy events, celebrations, welcome parties, ornamentally as well as food tonic supplement, so they have value, but the same time, they are cultivated at small area in the country due to several reason. However, they are climatically well-adopted and tolerate adverse environmental conditions. Lack of improved production technology and awareness about cultivation are major issues in every part of the globe. Unfortunately in agricultural research life, rose cultivation sector is most ignored around the world, less work, and less promotion of its cultivation causing reduced availability. Therefore, introduction of climatically well-adopted production technology is essential which provides briefly guide to formers from the scope of rose along with cultivation processes.
\end{abstract}

KEY WORDS: Climate, production, Rosa indica, technology

\section{THE ROSE}

Rose (Rosa indica L.), the king of flowers, commonly known as Gulab-Jo-Gul in sindhi, belongs to family Rosaceae. It is a woody and thorny plant, particularly rose is used as a symbol of love and beauty both in piece and in war. It is a shrub plant and has more than hundreds of species (Horn, 1992) and over 2000 cultivars (Kim et al., 2003). Large numbers of species are native from Asia while some species are native to Africa, North America, and Europe. The plant height goes up to $6 \mathrm{~m}$.

In Pakistan, mostly roses are planted in gardens as ornamental (PHEDC, 2012). For that, hybrids are considered and propagated because hybrid roses are more attractive. Usman et al. (2014) reported that Hyderabad and Karachi are two main agronomic zones, where the rose crop is greatly cultivated at commercial level. They are used as valuable for different purposes. Rose flavored ice cream, kulfi, and Rooh Afza drink is most popular in the Indo-Pak subcontinent. Rose flowers are also used in medicines and perfumes.

The rose production was much lessened in history; it is gained importance after $2^{\text {nd }}$ world war; early in the $20^{\text {th }}$ century, new technologies were adopted in flower industries utilization to production (Ozkan et al., 1997; Sayýn et al., 2003; Boran, 2008). Floriculture industries have high value in the world for development and promotion of rose while in the country shortage of industries is an issue. Rose grown from few decades, even Pakistan has most fertile soils and the climate favors to cut flowers, but main factors are a lack of awareness lack of resources and non-skilled labor. Flowers produced in the country are used locally, and small amount was exported to the Middle East while a large number of flowers are wasted (SMEDA, 2009). Leghari et al. (2015) reported that causes of small-scale farming of flowers in agriculture are a major issue due lack of awareness for flower cultivation, they clearly identified that climate of the country is most suitable.

Globally, the rose is a most popular flower at trade levels, and it is utilized in every event of local or international markets. Kenya, Japan, Italy, United States, Netherlands, Israel, and Colombia are leading rose producing countries. In past, the roses are grown only for preparation of products such as jam, rose water, and perfumes (Byczynski, 1997). Now, it is widely used, so now compared to the past, production of rose increased, but more attention is still required for their improved production specially in Pakistan. 


\section{IMPORTANCE OF ROSES}

There are so many uses of rose (R. indica L.). They are propagated as ornamentals, commercially rose oil used in manufacturing of perfumes, used as room refreshers, rose water has different uses in medicines, provide relief from soothes of mind, rose petals are antiseptic in nature, and used as an eye wash ingredient. It is enriched with vitamins such as vitamin A, C, D, E, and $\mathrm{B}_{3}$. For skin beauty, rose water is used in face masks for fair skin which maintains skin $\mathrm{pH}$ and controls extra oil. If one cup of rose water is used for hair shining, along shining it produces healthy hairs and in jams, jellies and in soup rose water used. The rose is a sign of love and peace and used as a gift, also for welcome parties, wedding ceremonies, and many religious events.

\section{CULTIVATION TECHNOLOGY OF ROSE}

\section{Soil Requirements}

Well-drained loamy, silty loam and sandy loam soil with $\mathrm{pH}$ between 6 and 7.5 is favorable for rose cultivation; however, rose can also grow and tolerate $\mathrm{pH}$ range up to 8 .

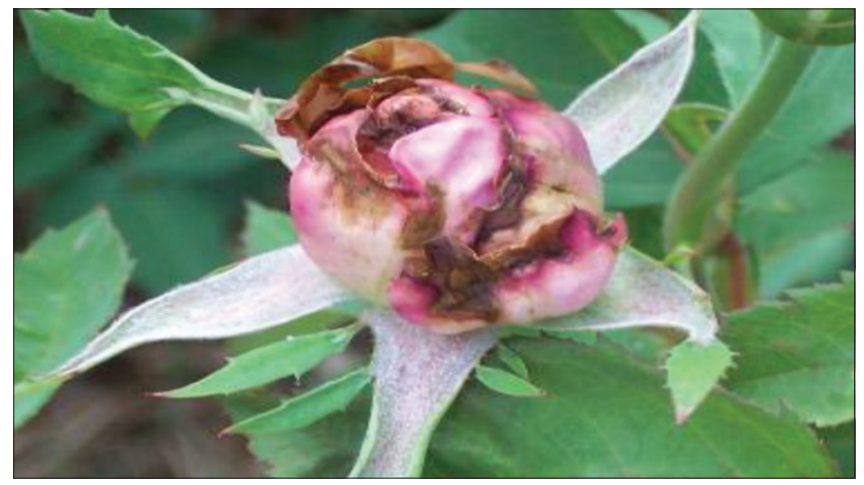

Figure 1: Rose thrips

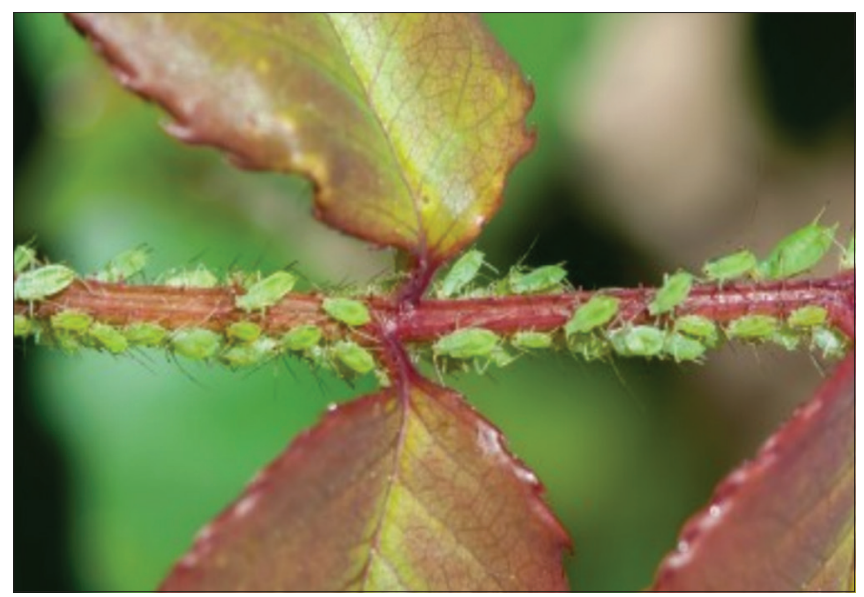

Figure 2: Rose aphids

\section{Fertilizer Needs}

Roses are highly feeder, thus requires fertilizer input, however, usually fertilizer is not supplied in good amount. While, nitrogen, phosphorus and potassium (NPK) being major plant nutrients, improve plant growth functions and enhances yield quality components. $\mathrm{N}$ normally involve in chlorophyll formation, thus vegetative growth, $\mathrm{P}$ helps in seedling growth and stimulate flowerin and fruit development etc and Potassium increase strength in stem, drought and disease resistance, it has direct role in quality constituent.

\section{Propagation Methods}

\section{Material required}

1. Razor blade

2. Small secateurs

3. Cutting of roses, etc.

\section{Procedure}

1. Take a growing tip from your plant 3" to 6" long with at least one leaf internodes two is better but not always possible

2. With a sharp edge razor blade, carefully cut of one or

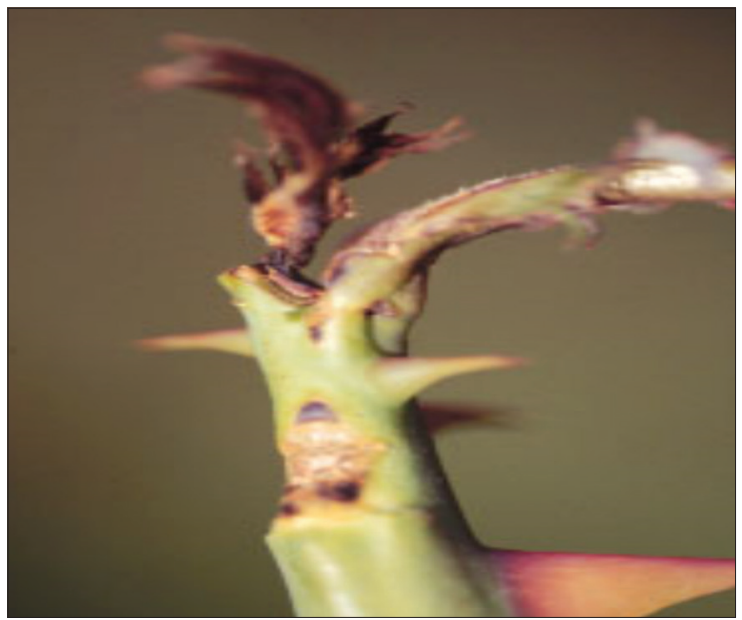

Figure 3: Rose midge

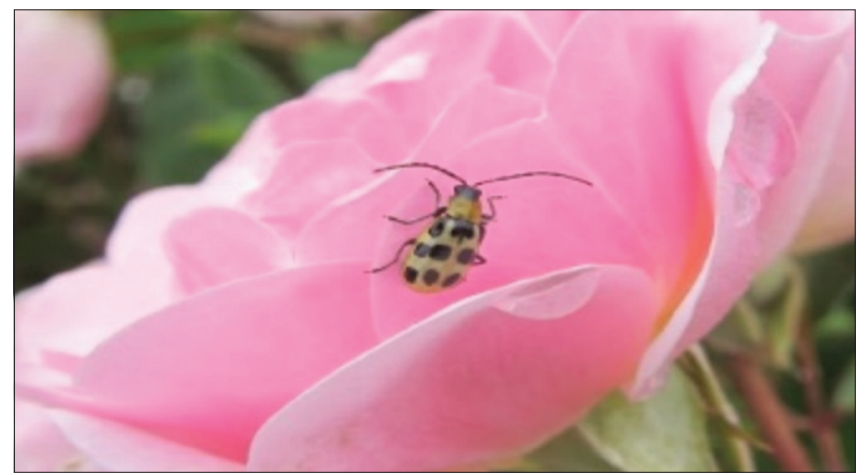

Figure 4: Spotted cucumber beetle 


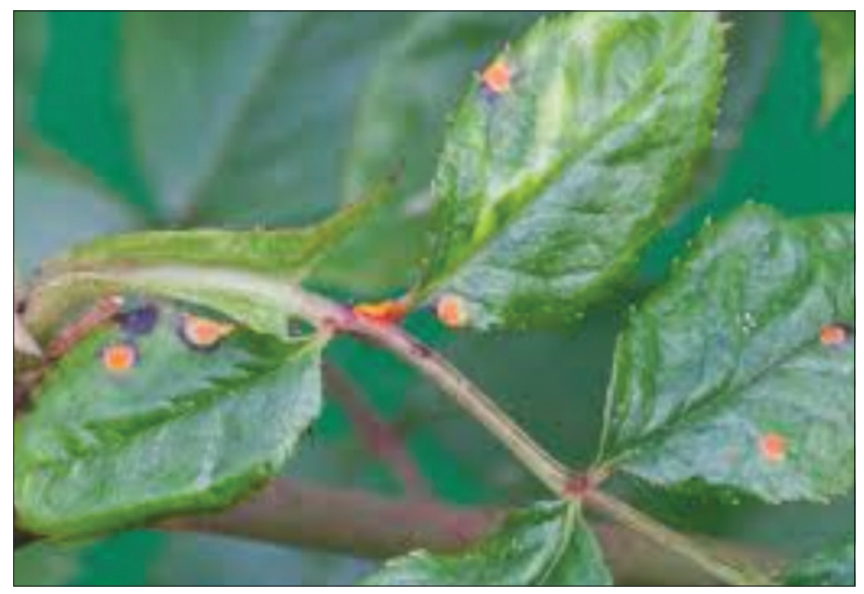

Figure 5: Rose rust

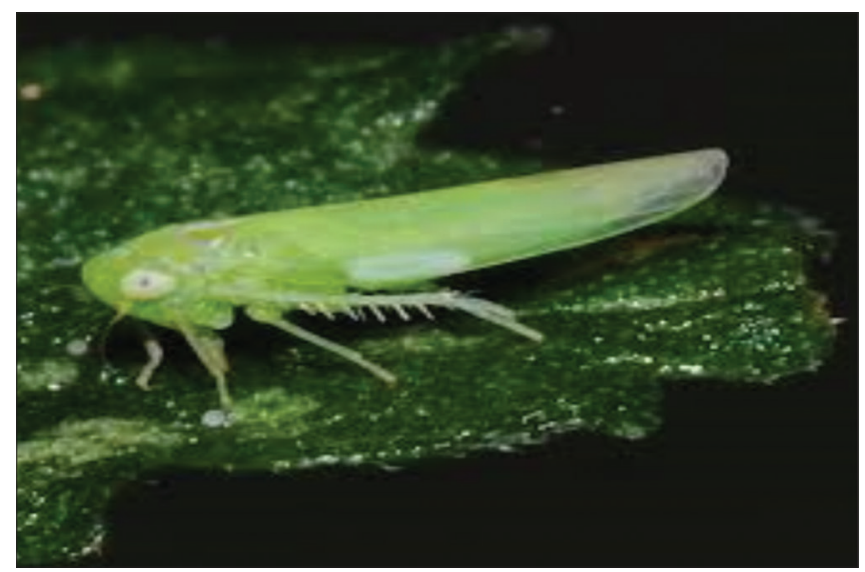

Figure 6: Rose leafhopper

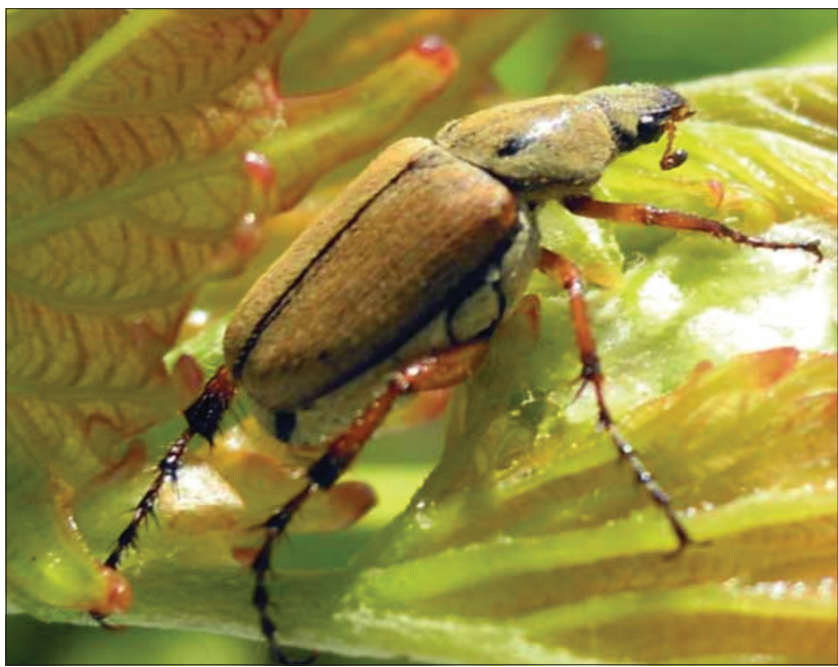

Figure 7: Rose chafer

two leaves or small branches flush with stem

3. Make a cut approximately $1 / 4$ " below the internodes where you just trimmed the leaves, cut at a $45-60^{\circ}$

4. Hold the backup behind the stem where you are going to cut, hold back tightly against the stem, this supports the stem and protect your fingers. Make this cut as

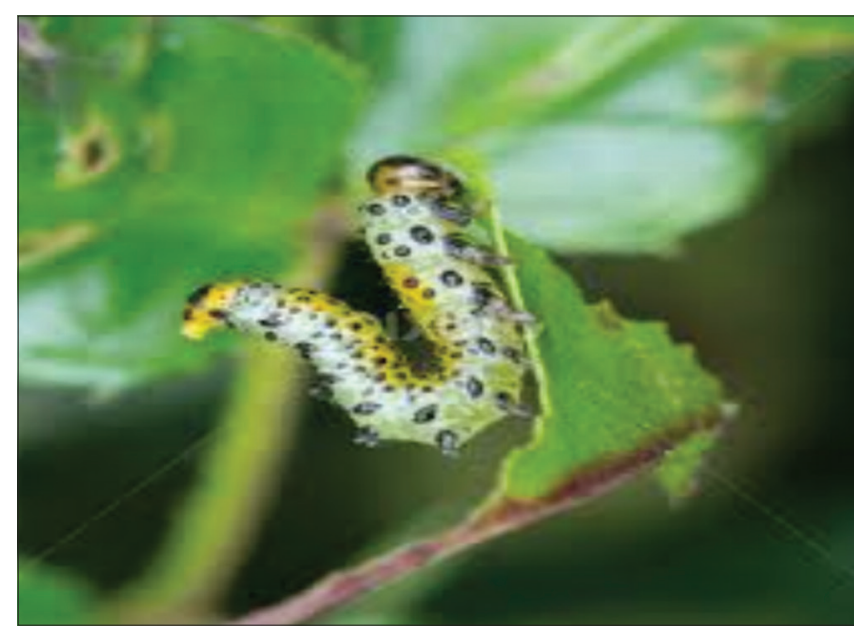

Figure 8: Rose caterpillar

quick and clean as you can, you do not want to tear or crush the stem

5. Quickly insert the cutting into the rooting hormone. If you use liquid hormone, you can lay the cutting soak for 30-60 s. With a gel type hormone you just dip the cutting and then insert into the growing medium.

After sustainable time, the root formation will be started, and a new plant obtained from cutting resemblance to their parent plant.

Some species of rose cultivated through stem cuttings as well as other sources

\begin{tabular}{|c|c|c|}
\hline Species & Color & Origin \\
\hline Carolinae & White, pink, and bright pink & North Africa \\
\hline Banksianae & White and yellow & China \\
\hline Caninae & Pink and white & $\begin{array}{l}\text { Asia, Europe, } \\
\text { and North Africa }\end{array}$ \\
\hline Chinensis & $\begin{array}{l}\text { White, pink, yellow, red, and } \\
\text { mixed-color }\end{array}$ & China and Burma \\
\hline Gallicanae & $\begin{array}{l}\text { Pink to crimson and striped } \\
\text { flowered roses }\end{array}$ & $\begin{array}{l}\text { Western Asia and } \\
\text { Europe }\end{array}$ \\
\hline Synstylae & $\begin{array}{l}\text { White, pink, and crimson } \\
\text { flowered roses }\end{array}$ & From all areas \\
\hline $\begin{array}{l}\text { Rosa (syn. sect. } \\
\text { Cinnamomeae) }\end{array}$ & $\begin{array}{l}\text { White, pink, lilac, mulberry, } \\
\text { and red roses }\end{array}$ & $\begin{array}{l}\text { From everywhere } \\
\text { but North Africa }\end{array}$ \\
\hline Gallicanae & $\begin{array}{l}\text { Pink to crimson and striped } \\
\text { flowered roses }\end{array}$ & $\begin{array}{l}\text { Western Asia and } \\
\text { Europe }\end{array}$ \\
\hline Pimpinellifolia & $\begin{array}{l}\text { White, pink, bright yellow, } \\
\text { mauve, and striped roses }\end{array}$ & $\begin{array}{l}\text { From Asia and } \\
\text { Europe }\end{array}$ \\
\hline
\end{tabular}

\section{Irrigation Requirement}

Rose requires a certain amount of irrigation, but a large number of rose genera are drought tolerant and able to mitigate the water deficit. The water requirement of rose depends on various factors.

\section{Temperature}

Temperature has directly effect on water requirement. Through high temperature, the rate of transpiration 


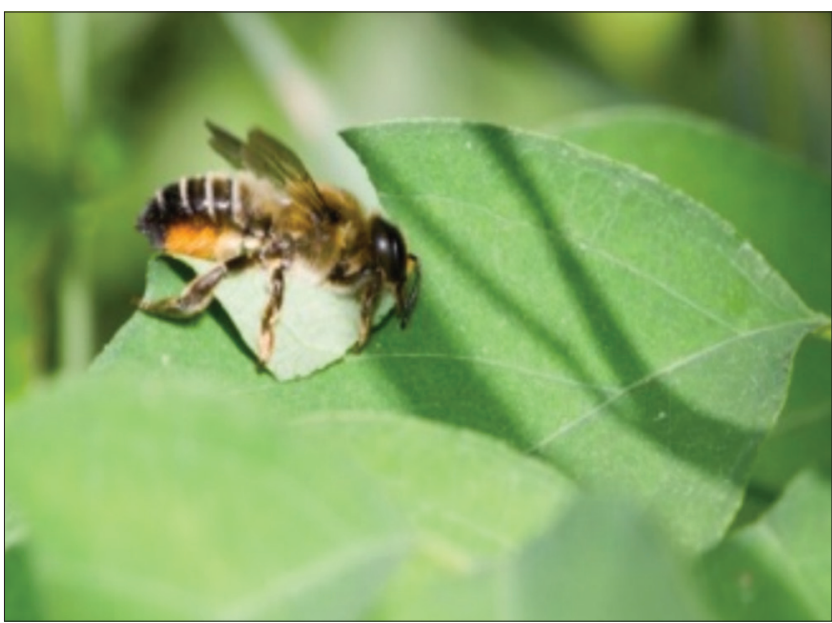

Figure 9: Rose leaf cutter bee

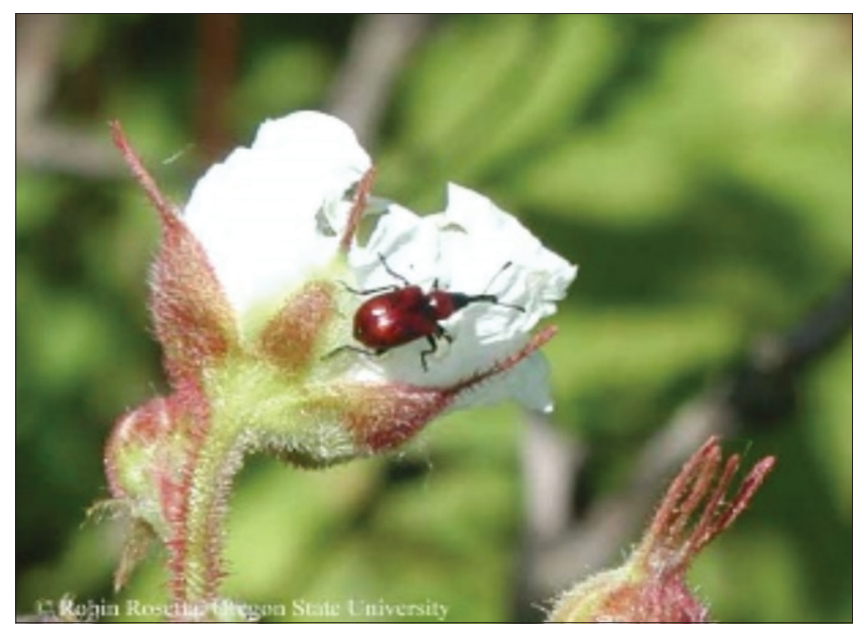

Figure 10: Curculio beetles

as well as evaporation increases results more water requires.

\section{Wind}

Through wind the rate of evapotranspiration increases, thus more water required.

\section{Humidity}

In high humidity level, less water required because of the slow rate of evaporation and transpiration and water holding capacity of soil.

\section{Insect Pests and Diseases}

Aphids, thrips, powdery mildew, rose rust, curculio beetles, rose wilt, downy mildew leaf-cutting bee, caterpillars, verticillium wilt, rose mosaic, leaf spot or blast, rose chafer and nematodes, etc., are insect pests and diseases of rose (Figures 1-10).

\section{Harvesting of Rose}

Commonly roses are harvested when they fully mature and open, and they are supplied to market or stored refrigerated conditions until to supply at the sale point.

\section{REFERENCES}

About rose. Available from: http://www.theflowerexpert. $\mathrm{com} / \mathrm{content} / \mathrm{mostpopular}$ flowers/rose.

Rooh Afza. The syrup that sweetens the subcontinent's summers. Available from: http://www.thenational.ae.

Boran S. Overview to Cut Flower Sector. Izmir, Turkey: Izmir Chamber of Commerce AR \& GE Bulletin; 2008.

Byczynski L. The Flower Farmer: An Organic Growers Guide to Raising and Selling Cut Flowers. White River Junction, VT: Chelsea Green Publishing; 1997.

Horn WA. Micropropagation of rose (Rosa sp. L.). In: BajajYP, editor. Biotechnology in Agriculture and Forestry. Berlin: 20-High-Tech and Micropropagation, Springer-Verlag; 1992. p. 320-40.

Kim CK, Chung JD, Jee SO, Oh JY. Somatic embryogenesis from in vitro grown leaf explants of Rosa hybrida L. J Plant Biotechnol 2003;5:169-72.

Leghari SJ, Soomro FA, Leghari Z, Maher PA, Minhas AA, Soomro AA, et al. Causes of low level farming of flowers in indus valley. Am Res Thoughts 2015;1:2636-46.

Ozkan B, Celikyurt MA, Karaguzel O, Akkaya F. Production, structure and main marketing problems of export oriented cut flower industry in Turkey. Acta 1997;491:481-7.

PHEDC. Pakistan Horticulture Development and Export Company. Ministry of Commerce, Government of Pakistan; 2012. Available from: http://www.phdeb.org/phs.php.

Rose flavored ice cream with rose petals. Available from: http://www.ecurry.com.

Rose. Available from: http: / / www.en.wikipedia.org/wiki/Rose.

Roses: Cultural Practices and Weed Control. Available from: http: / / www.ipm.ucdavis.edu/PMG/PESTNOTES/ pn7465.html.

Sayýn C, Özkan B, Karagüzel O, Tascýoglu Y. Production, Marketing of Cut Flowers and Policies Persude in Turkey; 2003.

SMEDA. Pre-Feasibility Study Cut Flowers farm (Roses). Small and Medium Enterprises Development Authority, Government of Pakistan; 2009.

Usman M, Ashfaq M, Taj S, Abid M. An economic analysis of cut-rose flower in Punjab. Pakistan. J Anim Plant Sci 2014;24:651-5.

What Type of Climate do Roses Grows in? Available from: http://www.ehow.com/info _775 5917_type-climatedo-roses-grow.html. 